\title{
Evaluation of adipokines in children with cystic fibrosis
}

\author{
Ocena stężenia adipokin u dzieci z mukowiscydozą
}

\author{
Edyta Machura ${ }^{1}$, Maria Szczepańska' ${ }^{1}$ Elżbieta Świętochowska' ${ }^{2}$ Franciszek Halkiewicz' \\ Małgorzata Barć-Czarnecka', Katarzyna Ziora ${ }^{1}$, Dariusz Ziora ${ }^{3}$
}

${ }^{1}$ Chair and Department of Pediatrics, Medical University of Silesia, School of Medicine with the Division of Dentistry, Zabrze, Poland

${ }^{2}$ Department of Medical and Molecular Biology, Medical University of Silesia, School of Medicine with the Division of Dentistry, Zabrze, Poland

${ }^{3}$ Chair and Department of Pneumonology and Tuberculosis, Medical University of Silesia, School of Medicine with the Division of Dentistry, Zabrze, Poland

\begin{abstract}
Introduction: Patients with CF present numerous pathological conditions such as malnutrition, depletion of fat-free mass, metabolic disturbances (abnormal glucose metabolism, increased insulin resistance, chronic energy deficit, local and chronic inflammation), which could affect or be associated with altered adipokines concentration.

Material and methods: We aimed in this study to investigate the levels of selected adipokines such as resistin, apelin, adiponectin to demonstrate their application as possible markers of inflammation.

Results: Serum level of resistin was higher $(p<0.001)$ and adiponectin - lower $(p=0.02)$ in CF children than in healthy children. There was no difference in serum apelin level between two examined groups. However, values of adiponectin/BMI and apelin/BMI ratios in CF did not differ significantly from controls. Higher values of resistin/BMI ratio in CF in comparison to controls were observed Serum resistin/ /adiponectin ratio was significantly higher in CF patients than in controls $(\mathrm{p}<0.0001)$. Resistin/BMI ratio correlated negatively with $\mathrm{FEV} \mathrm{V}_{1}$ (R: $-48, p<0.043)$. Serum resistin/adiponectin ratio correlated negatively with $F_{1} V_{1} / F V C(R:-49, p=0.04)$, Adipokines showed no correlation with BMI and BMI-SDS, glucose, total cholesterol, and LDL-, HDL-cholesterol, triglyceride serum levels. Spirometric parameters FEV $_{1}$, FVC, VC correlated negatively with serum glucose levels (R: $-0.55, \mathrm{p}<0.018$; R: $-0.65 \mathrm{p}<0.0025 ; \mathrm{R}:-0.76$, $\mathrm{p}<0.0008$ respectively). $\mathrm{FEV}_{1}$ and FVC correlated positively with BMI-SDS (R: 0.58, p < 0.01; R: $0.5, \mathrm{p}<0.036$, respectively).

Conclusions: A significant increase in resistin concentration expressed also as resistin/BMI, and resistin/adiponectin ratios, observed in children with CF may suggests that this adipokine is involved in the inflammatory process underlying the disease and is related to worse spirometric parameters describing airways obstruction. (Endokrynol Pol 2018; 69 (2): 128-134)
\end{abstract}

Key words: cystic fibrosis, adipokines, resistin, apelin, adiponectin, children, inflammation

\section{Streszczenie}

Wstęp: Pacjenci z mukowiscydozą (CF) ujawniają liczne stany patologiczne, takie jak niedożywienie, zmniejszenie beztłuszczowej masy ciała, zaburzenia metaboliczne m.in. nieprawidłowy metabolizm glukozy, zwiększoną insulinooporność, przewlekły deficyt energetyczny, miejscowe i przewlekłe stany zapalne, które mogą wpływać lub być związane ze zmianami stężenia adipokin.

Materiał i metody: Celem aktualnego badania było oznaczenie stężenia wybranych adipokin, takich jak rezystyna, apelina, adiponektyna w celu wykazania możliwości ich zastosowania jako markerów stanu zapalnego.

Wyniki: Stężenie rezystyny w surowicy było wyższe $(p<0.001)$ a adiponektyny — niższe $(p=0,02)$ u dzieci z CF niż u zdrowych dzieci. Nie stwierdzono różnicy w stężeniu apeliny w surowicy krwi pomiędzy tymi dwoma badanymi grupami. Wartości wskaźników adiponektyna/BMI i apelina/BMI u dzieci z CF nie różniły się jednakże znacząco od stwierdzanych w grupie kontrolnej. Obserwowano wyższe wartości wskaźnika rezystyna/BMI w CF w porównaniu z grupą kontrolną Wskaźnik rezystyna/adiponektyna w surowicy był znacząco wyższy u pacjentów z CF niż u osób z grupy kontrolnej ( $\mathrm{p}<0.0001)$. Stosunek rezystyna/BMI korelował negatywnie z FEV1 (R: -48, $\mathrm{p}<0.043)$. Stosunek rezystyna/adiponektyna w surowicy korelował negatywnie z FEV1 / FVC (R: $-49, \mathrm{p}=0,04)$. Stężenie adipokin w surowicy nie wykazało korelacji z BMI i BMI-SDS, stężeniem glukozy, cholesterolu całkowitego, stężeniem cholesterolu LDL i HDL, stężeniem triglicerydów. Parametry spirometryczne FEV1, FVC, VC korelowały negatywnie ze stężeniem glukozy w surowicy (R: - 0,55 , $\mathrm{p}<0.018, \mathrm{R}:-0,65 \mathrm{p}<0.0025$, R: -0,76, p < 0.0008). FEV1 i FVC wykazywały dodatnią korelację z BMI-SDS (R: 0,58, p < 0,01, R: 0,5, $\mathrm{p}<0.036)$.

Wnioski: Znaczne zwiększenie stężenia rezystyny wyrażone również jako wskaźnik rezystyna /BMI oraz stosunek rezystyna/adiponektyna, obserwowane u dzieci z CF może sugerować, że ta adipokina jest zaangażowana w proces zapalny leżący u podstaw choroby i jest związana z pogorszeniem parametrów spirometrycznych opisujących niedrożność dróg oddechowych.(Endokrynol Pol 2018; 69 (2): 128-134)

Słowa kluczowe: mukowiscydoza, adipokiny, rezystyna, apelina, adiponektyna, dzieci, stan zapalny 


\section{Introduction}

Cystic fibrosis (CF) is an untreatable and lifeshortening inherited autosomal recessive disease with multiorgan manifestation. It is caused by different mutations in a single gene, localized on the long arm of chromosome 7 at position q31.2., which codes Cystic Fibrosis Transmembrane Conductance Regulator (CFTR). CFTR protein is a cAMP-activated chloride channel expressed at the apical membrane on the surface of epithelial cells lining the airways, gastrointestinal tract, cells of exocrine pancreas, airway submucosal and sweat glands [1]. To date, more than 1900 mutations of the CFTR gene have been identified. $\triangle \mathrm{F} 508$ - deletion of phenylalanine 508 is the most prevalent mutation, with approximately $90 \%$ of all CF patients carrying it on at least one allele, and unfortunately it is associated with a severe clinical phenotype. The defective or absent CFTR protein results in poor transport of salt and water into and out of the cells in number of organs. The extent of clinical manifestations is highly heterogeneous in distinct organs. Leading symptoms of typical CF include increased electrolytes concentration in sweat, exocrine pancreatic insufficiency and progressive pulmonary dysfunction, which is responsible for more than $80 \%$ of CF-related deaths [1]. CF-associated bronchopulmonary disease is characterized by multiply alterations including mucostasis, mucus hypersecretion, and chronic neutrophilic inflammation with recurrent bacterial infections, mainly caused by Pseudomonas aeruginosa and Staphylococcus aureus [2, 3].

Other CF clinical manifestations comprise chronic rhinosinusitis, hepatic and intestinal disorders, diabetes mellitus, male infertility [1]. Cystic fibrosis is associated with malnutrition, depletion of body fat, but increased percentage of visceral adipose tissue $[4,5]$.

Adipokines are protein mediators secreted by the adipose tissue, which were found to be associated with the chronic low-grade inflammation process present in inflammatory diseases and chronic disturbances of metabolism [6-9]. With related receptors extensively dispersed throughout the body, including the lungs, adipokines may be a contributing factor underlying the complications of $\mathrm{CF}$.

We have planned to investigate serum levels of selected adipokines such as resistin, apelin, adiponectin to demonstrate their application as possible markers of inflammation.

Resistin is expressed in brown and white adipose tissue and is a member of cysteine rich proteins family, called resistin - like molecules (RELMs), also known as the FIZZ family (found in inflammatory zones). Circulating monocytes and macrophages seem to be responsible for resistin production in human. Resistin has proinflammatory properties and upregulates the expression of monocyte chemo-attractant protein-1 (MCP-1) as well as vascular cell adhesion molecule - 1 (VCAM-1) and intercellular adhesion molecule - 1 (ICAM-1) in endothelial cells, which have been known to contribute in the pathogenesis of inflammation [10, 11].

Adiponectin is a well-known adipokine that has anti-diabetic, anti-inflammatory and anti-oxidative effects [12]. Low serum adiponectin levels are related to obesity, insulin resistance, diabetes mellitus and cardiovascular disease, and lipodystrophy $[8,9]$. On the other hand higher adiponectin serum levels have been reported in patients with deficits of energy in anorexia nervosa and bulimia and patients with bronchiectases with fat-free depletion or CF $[5,8,9]$.

Apelin (APE) is a novel bioactive peptide identified as the endogenous ligand of the previously discovered "orphan" G-protein-coupled receptor named APJ, isolated by Tatemoto et al. [13] from bovine stomach extracts in 1998. Several different isoforms of APE have been identified that are thought to exist in vivo. The predominant form of circulating APE is believed to be APE-36; however, shorter C-terminal fragments with biological activity have been found, including APE-17, APE-16, APE-13 and its pyroglutamylated form (APE-p[Glu]-13), and APE-12 [14, 15]. It has been demonstrated that the biological activity of APEs is related inversely to the peptide length; thus, APE12 is the most potent isoform. APE belongs to the adipokines group because its mRNA expression has been demonstrated in mature adipocytes and vascular stroma of fat tissue in rodents and humans as well as in murine preadipocyte cell lines (3T3F442A) $[16,17]$. APE peptide expression has been also detected in CNS neuronal cells (APE-p[Glu]-13 and APE-17), placenta, breast in pregnant and lactating women (APE-36 and APE-p[Glu]-13), pancreas, kidneys, prostate, testes (APE-36), uterus (APE-36), gastrointestinal tract, and osteoblasts $[18,19]$.

This multifunctional apelinergic system is also highly expressed in pulmonary tissue. APJ is expressed in bronchial and alveolar epithelial cells, in small pulmonary blood vessels in the endothelium and in the smooth muscle cells [20].

Only a few reports conducted in adult patients with CF focus on the pro-inflammatory role of leptin and anti-inflammatory of adiponectin, which potentially may affect inflammation and glucose tolerance as well as nutritional status in this group [5, 21, 22]. However, recent human data are inconclusive regarding the independent association between serum leptin or serum adiponectin and CF symptoms severity in adults. 
The potential association between $\mathrm{CF}$ and resistin and apelin has not been explored in CF so far and remains obscure.

We hypothesized, that resistin, apelin and adiponectin also participate in CF pathophysiology and are associated with the severity of CF clinical features.

\section{Material and methods}

The study group comprised 21 children (aged 4.5-18 years; mean age $11.34 \pm 0.37$ years) with stable CF. The diagnosis of CF was established by sweat test and later confirmed by genetic tests in all subjects. All patients were treated according to European and U.S. guidelines [24]. Patients with pulmonary exacerbation were excluded from this study. In all children the following parameters were assessed: patient history and physical examination, anthropometric parameters, sputum and blood samples, and lung function tests.

The control group consisted of 22 healthy children (aged 4-17 years; mean age $10.9 \pm 4$.4years). Children from the control group attended the outpatient pediatric clinic for non-immunological, non-inflammatory health problems and needed venous puncture.

The present study was approved by Ethics Committee of the Medical University of Silesia in Katowice and written informed consent was obtained from children's parents.

\section{Laboratory assays}

Blood samples for assays were collected in the fasting state between $8-9^{30}$ am. After centrifugation at $1000 \times$ $g$ for $15 \mathrm{~min}$ at $4^{\circ} \mathrm{C}$, the serum samples were frozen at $-20^{\circ} \mathrm{C}$ until analyzed. The absorbance measurements for all samples were performed using the Quant Universal Microplate Spectrophotometer (BioTek Instruments Inc., Winooski, VT) determined on the basis of the standard curve made for a series of dilutions of the standards available in the kit. Acquired data were analyzed using KCJunior Software (v.1.31.5, Bio-Tek Instruments,Winooski, VT, USA).

Serum resistin concentration was measured by commercially available enzyme-linked immunosorbent assay kit (Mediagnost, Reutlingen, Germany) as described in our previous study [24] . The concentration of resistin was determined on the basis of standard curve carried out for serial dilution available in kit standards (human recombinant resistin). Immunocomplex detection was determined on the basis of reaction with rabbit polyclonal antibody antihuman immunoglobulin (IgG) conjugated with horseradish peroxides and then with TMB substrate solution (TMB substrate, slow kinetic, Sigma-Aldrich, St. Louis, MO, USA). The sensitivity for resistin was $0.012 \mathrm{ng} / \mathrm{mL}$, and the intra- and interassay CV was $4.66 \%$ and $4.79 \%$, respectively.

Serum apelin-12 concentration was determined using commercial human Apelin-12 enzyme immunoassay kit (Phoenix Pharmaceuticals Inc., Burlingame, CA) following the manufacturer's instructions as described in our previous study [25]. Serum samples were extracted before the assay, to isolate analyzed peptides. Buffer A (1\% trifluoroacetic acid aqueous solution), buffer B (60\% acetonitrile solution in $1 \%$ trifluoroacetic acid solution), and SEP-PAK C chromatographic columns (Waters Associates, Milford, MA) were used for extraction. Before the analysis, after lyophilisation, obtained extract was dissolved in the assay buffer.

The sensitivity was $0.07 \mathrm{ng} / \mathrm{mL}$ for Apelin-12 kit; the intraassay coefficient of variance $(\mathrm{CV})$ was $5 \%$ or less, and the extraassay CV was $14 \%$.

Serum adiponectin concentration was measured by commercially available enzyme-linked immunosorbent assay kit (Bio-Vendor, LLC, USA). The procedure was done according to manufacturer's instruction. The sensitivity for adiponectin was $0.7 \mathrm{ng} / \mathrm{mL}$, and the intra- and interassay CV was $7.0 \%$ and $8.2 \%$, respectively.

All statistical analyses were performed using (MedCalc ver. 12.4.0.0) and $p$ values of $<0.05$ were considered to be significant. To compare the characteristics of the subgroups the Mann-Whitney U-test was applied. Correlations were analyzed with Spearman tests. Besides absolute values of examined adipokines concentration in serum we additionally expressed results in relation to $\mathrm{BMI}$ as apelin/BMI, adiponectin/BMI and resistin/BMI ratios.

\section{Results}

The characteristics of 20 children with CF and 22 healthy control subjects is presented in Table I. Mean values of BMI in CF group were significantly lower than in control group.

The mean values of serum levels of adiponectin, apelin, resistin in all children are shown in Table II.

Serum levels of resistin were significantly higher and adiponectin significantly lower in CF children than in healthy children $(p=0.001$ for resistin, $p=0.001$ for adiponectin). There was no difference in serum apelin levels between two examined groups. However, values of adiponectin/BMI ratios and apelin/BMI ratios in $\mathrm{CF}$ did not differ significantly from controls, but still were observed significantly higher values of resistin/BMI ratios in CF in comparison to controls. Serum resistin/ adiponectin ratio was significantly higher in CF patients than in controls $(p<0.0001)$ (Fig. 1).

We have documented few correlations between adipokine levels and other parameters. Age of CF 
Table I. Characteristics of examined children

Tabela I. Charakterystyka badanych grup dzieci

\begin{tabular}{|c|c|c|c|}
\hline Characteristics & Children with $\mathrm{CF}(\mathrm{n}=21)$ & Healthy Children ( $n=22$ ) & $\mathbf{P}$ \\
\hline Age [years] & $11.7 \pm 1.6$ & $10.9 \pm 4.4$ & ns \\
\hline Sex $[n]$ & $\mathrm{F}: 11 ; \mathrm{M}: 10$ & F:12; M:10 & \\
\hline Height $[\mathrm{cm}]$ & $144 \pm 9.84$ & $144.9 \pm 21.7$ & ns \\
\hline Weight $[\mathrm{kg}]$ & $36.8 \pm 15.7$ & $39.5 \pm 13.0$ & 0.02 \\
\hline BMI $\left[\mathrm{kg} / \mathrm{m}^{2}\right]$ & $17.1 \pm 1.4$ & $18.3 \pm 0.98$ & 0.03 \\
\hline BMI-SDS & $-0.58 \pm-0.71$ & $0.95 \pm 0.82$ & 0.01 \\
\hline $\mathrm{CRP}[\mathrm{mg} / \mathrm{dL}]$ & $3.43 \pm 1.77$ & $0.54 \pm 0.17$ & 0.05 \\
\hline WBC & $8.9 \pm 1.42$ & $6.63 \pm 0.85$ & 0.01 \\
\hline Fasting Glucose [mgdL] & $94.43 \pm 4.12$ & $84.36 \pm 2.67$ & 0.003 \\
\hline $\mathrm{TC}[\mathrm{mmol} / \mathrm{L}]$ & $3.42 \pm 0.36$ & $3.14 \pm 0.28$ & ns \\
\hline LDL cholesterol [mmol/L & $1.76 \pm 0.26$ & $1.79 \pm 0.41$ & ns \\
\hline HDL cholesterol $[\mathrm{mmol} / \mathrm{L}$ & $1.2 \pm 0.12$ & $1.27 \pm 0.28$ & ns \\
\hline $\mathrm{TG}[\mathrm{mmol} / \mathrm{L}]$ & $1.08 \pm 0.23$ & $1.26 \pm 0.77$ & ns \\
\hline AspAT [IU/mL] & $32 \pm 0.8$ & $25.41 \pm 4.16$ & ns \\
\hline AIAT $[\mathrm{IU} / \mathrm{mL}]$ & $33.5 \pm 72$ & $15.88 \pm 3.02$ & 0.001 \\
\hline FEV1 [\% predicted] & $65.62 \pm 9.73$ & $95.82 \pm 1.7$ & 0.0001 \\
\hline FVC [\% predicted] & $67.11 \pm 8.6$ & $94.11 \pm 2.8$ & 0.0001 \\
\hline FEV1/FVC [\%] & $78.87 \pm 6.28$ & $90.03 \pm 1.5$ & 0.0001 \\
\hline
\end{tabular}

Data are shown as mean $\pm 1,96 *$ SEM

BMI — body mass index; BMI-SDS — body mass index standard deviation scores; CRP — C-reactive protein; HDL-C — high-density lipoprotein cholesterol; IU — international unit; LDL-C — low-density lipoprotein cholesterol; SE — standard error; TC — total cholesterol; TG — triglyceride; FEV ${ }_{1}$ - forced expiratory volume in 1 second; FVC — forced vital capacity

Table II. Mean values of adipokine serum levels in children with cystic fibrosis and healthy children Tabela II. Średnie wartości stężeń adipokin w surowicy krwi u dzieci z mukowiscydozq i u dzieci zdrowych

\begin{tabular}{lccc}
\hline Adipokines & CF & Healthy subjects & P value \\
\hline Adiponectin $[\mu \mathrm{g} / \mathrm{mL}]$ & $13.6 \pm 0.69$ & $14.98 \pm 0.94$ & 0.02 \\
Adiponectin $/ \mathrm{BMI}$ & $0.82 \pm 0.06$ & $0.84 \pm 0.06$ & 0.6 \\
\hline Apelin $[\mathrm{pg} / \mathrm{mL}]$ & $82.9 \pm 4.53$ & $81.4 \pm 4.95$ & 0.6 \\
Apelin pg/BMl & $4.97 \pm 0.38$ & $4.53 \pm 0.31$ & 0.1 \\
\hline Resistin $[\mathrm{ng} / \mathrm{mL}]$ & $8.7 \pm 0.3$ & $5.6 \pm 0.44$ & $<0.001$ \\
Resistin $/ \mathrm{BMI}$ & $0.53 \pm 0.03$ & $0.31 \pm 0.03$ & $<0.001$ \\
\hline Resistin $\left[\mathrm{ng} / \mathrm{mL}\right.$ /adiponectin $\times 10^{-3}$ & $0.66 \pm 0.55$ & $0.38 \pm 0.04$ & $<0.0001$ \\
\hline
\end{tabular}

Data are shown as mean $\pm 1.96 *$ SEM

patients correlated positively with CRP and resistin levels (R: 0.7, p < 0.0006; R: 0.49, p < 0.021, respectively) and negatively with adiponectin serum levels (R:-0.51, p < 0.01) and BMI-SDS ( $\mathrm{R}-0.55, \mathrm{p}<0.0096)$. BMI of CF children correlated with BMI-SDS (R:0.6, $\mathrm{p}<0.0018)$, TG (R: 0.8, $\mathrm{p}<0.0001)$ and CRP levels (R: 0.52, $\mathrm{p}<0.0017$ ). CRP correlated with resistin levels (R: 0.58, $\mathrm{p}<0.0064)$, TG levels (R: 0.65, $\mathrm{p}<0.0044)$, BMI (R:0.52, $\mathrm{p}<0.018$ ). Spirometric parameters $\mathrm{FEV}_{1}$ and FVC and VC correlated negatively with serum glucose levels
(R: $-0.55, \mathrm{p}<0.018 ; \mathrm{R}:-0.65 \mathrm{p}<0.0041 ; \mathrm{R}:-0.76$, $\mathrm{p}<0.0008$ respectively). FEV 1 and FVC correlated positively with BMI-SDS (R:0.58, p < 0.01; R: 0.5, $\mathrm{p}<0.036$, respectively). Resistin/BMI correlated negatively with $\mathrm{FEV}_{1}(\mathrm{R}:-0.48, \mathrm{p}<0.043$ ) (Fig. 2). Serum resistin/ adiponectin ratio correlated negatively with $\mathrm{FEV}_{1} / \mathrm{FVC}$ (R: $-0.49, \mathrm{p}=0.04$ ) (Fig. 3). Adiponectin and apelin showed no correlation with BMI and BMI-SDS, glucose, total cholesterol and LDL-, HDL-cholesterol, triglyceride serum levels and spirometric parameters. 


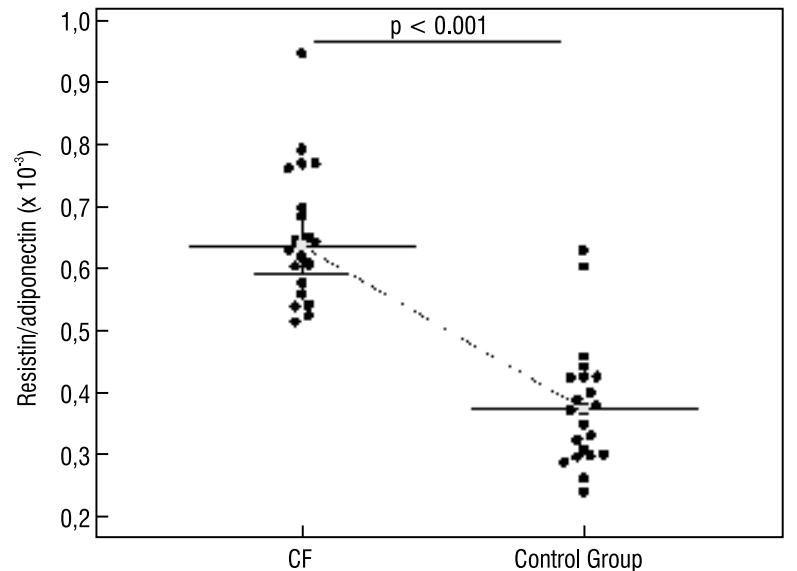

Figure 1. Comparision resistin/adiponectin ratio between $C F$ patient and healthy and control group

Rycina 1. Porównanie wskaźnika rezystyna/adiponektyna u dzieci z mukowiscydoza i u dzieci zdrowych

\section{Discussion}

CF patients present numerous pathological conditions such as malnutrition and depletion of fat free mass, metabolic disturbances including abnormal glucose metabolism, increased insulin resistance, chronic energy deficit, local and chronic inflammation, all of which could affect or be associated with altered adipokines concentration [1, 2-4].

The results obtained in the current study showed that there was significant increase of resistin, concentrations in CF children in comparison with healthy controls. The role of resistin in patients with CF has not yet been investigated, so to our best knowledge is the first report showing this pro-inflammatory adipokine increase in CF children.

Macrophage exposure to resistin has been shown to induce expression of tumor necrosis factor alpha (TNF-alpha) and IL-12, IL-6. Furthermore, in human epithelial cells, RELMb induced increased proliferation, mucin and growth factor production, suggesting a potential contribution to airway remodeling. Interestingly adiponectin inhibits some effect of resistin [8, 26, 27]. Increasing evidence indicates that resistin plays an important regulatory role in insulin resistance, and several pathological processes including asthma, cardiovascular disease, and inflammatory bowel disease [7, 24, 26-28]. In patients with asthma and chronic obstructive pulmonary disease resistin correlated negatively wit FEV1 [26-28]. In our previous study resistin/BMI ratio correlated inversely with FVC of asthmatic children [24]. In several pathophysiological conditions, plasma resistin concentrations have been associated with circulat-

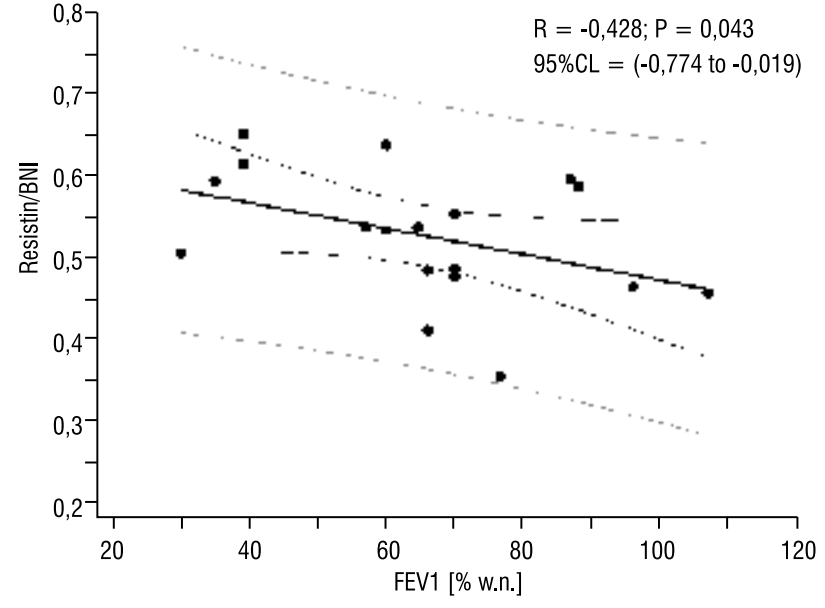

Figure 2. Correlation between resistin/BMI ratio and $F E V_{1}$ Rycina 2. Analiza korelacji pomiędzy wskaźnikiem rezystynal /BMI i FEV

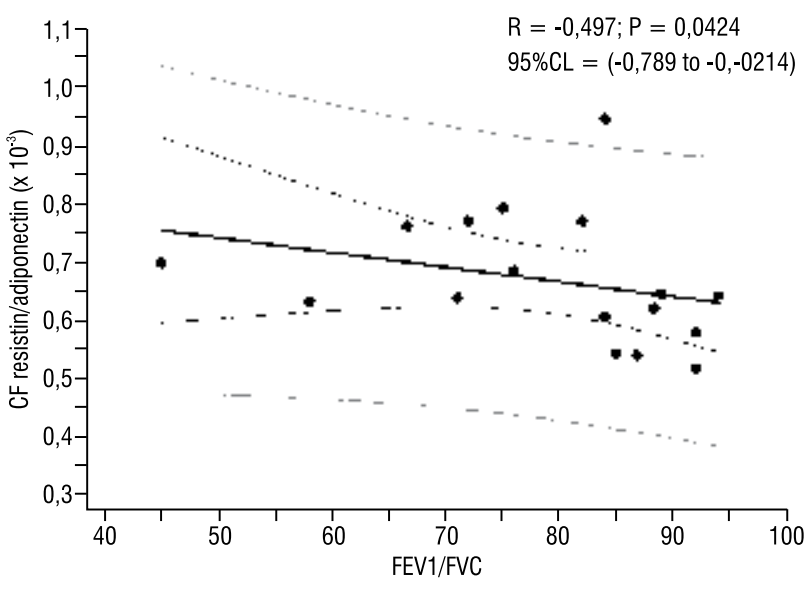

Figure 3. Corelation between resisin/adiponectin ratio in $C F$ and $F E V_{1} / F V C$

Rycina 3. Analiza korelacji pomiędzy wskaźnikiem rezystynal ladiponektyna i FEV/FVC u dzieci z mukowiscydozq

ing pro-inflammatory mediators, including CRP [28]. In our study resistin levels correlated positively with CRP, which is a commonly recognized acute phase protein. Recently Ballantyne et al. [27] suggested that balance between resistin and adiponectin is important in asthma pathology and resistin/adiponectin ratio is a positive predictor of $\mathrm{FEV}_{1}$ and is higher in asthmatics who have more severe disease. In our present study we also observed higher resistin/ adiponectin ratio in CF compared to controls, which indicate the relative excess of proinflammatory adipokine resistin and relative deficit antinflammatory adipokine - adiponectin. Moreover resistin/adiponectin ratio in CF inversely correlated with $\mathrm{FEV}_{1} / \mathrm{FVC}$. 
Resistin is also implicated in the development of atherosclerosis, by affecting the course of chronic inflammatory response and cell proliferation and differentiation. [35]. In our study, however we have not found relationship of adipokines with lipid metabolism parameters. The study evaluating the risk of atherosclerosis in patients with $\mathrm{CF}$, which purpose is to examine $\mathrm{CF}$ patients in relation to the exogenous and endogenous factors that influence the course of the disease will put a new light on this topic [36].

In our study serum adiponectin was significantly lower in CF group than in control group, but adiponectin/BMI ratio did not differ from healthy children. Adiponectin is primarily considered to be anti-inflammatory due to its dual role in inhibiting the effects of pro-inflammatory cytokines (e.g. TNF alfa induced IL18, IL-6) and inducing expression of anti-inflammatory cytokines (e.g. IL-10 and IL1RA) [6, 7]. In low levels may be partially responsible for excessive inflammatory response which plays a key role in chronic bacterial infection and pulmonary exacerbation and lung function decline in CF patients.

One of the major characteristic symptoms of CF airways is chronic inflammation. The CF airways contain several proinflammatory mediators including TNF-alfa, IL-1 beta, IL-6, IL-8, MIF [2, 3]. It has been suggested that adiponectin may have a protective role in inflammatory lung disease such as asthma but not in patients with COPD [29]. Several studies investigated adiponectin levels in $\mathrm{CF}$, with inconsistent results. In adult $\mathrm{CF}$ serum adiponectin concentrations were higher than in healthy subjects, especially in patients with normal nutrition and in patients with liver disease $[5,30]$. In one study the lowest adiponectin concentration among young malnourished patients was shown [5] similarly to our study. In other study any alteration in adiponectin levels despite insulin resistance, glucose intolerance and subclinical chronic inflammation was detected [31-33].

We did not observe any correlation between anthropometric parameters, BMI, BMI-SDS and lung function and adiponectin levels. On the other hand adiponectin concentration was negatively correlated with age of children. The discrepancy between studies could be related to different age, stage of disease and organ involvement, nutritional status, metabolic disturbance. Additionally above mentioned authors did not adjust results to BMI or to free fat mass to diminished the potential bias.

In our previous study we demonstrated that serum levels of another adipokine i.e. APE-12 and APE-12/BMI ratio are increased in asthmatic children, particularly in girls [25]. In our CF patients with relative malnutrition serum apelin concentrations were similar to controls. It is not surprisingly because increased apelin expres- sion in adipose tissue could contribute to apelin plasma levels. It is assumed that the overproduction of apelin in obesity could be a protective mechanism before onset of an obesity-related disorder, such as hypertension or cardiovascular dysfunction [14, 15]. Well known proinflammatory cytokine Tumor necrosis factor-alpha $(\mathrm{TNF}-\alpha)$, that has been implicated in many aspects of the airway pathology in asthma [34], may act as a direct up-regulator of apelin expression in adipocytes in both obese and lean subjects.

In conclusion, a significant increase in resistin concentration expressed also as resistin/BMI, and resistin/ adiponectin ratios, observed in children with CF may suggests that this adipokine is involved in the inflammatory process underlying the disease and is related to worse spirometric parameters describing airways obstruction. Although this was a cross-sectional study with a relatively small sample size we believe that our data may create a pilot knowledge for further studies evaluating the possible role of adipokines in $\mathrm{CF}$ pathogenesis.

\section{Funding source}

This study was supported by grant no KNW-1-132/k/5/0 from the Medical University of Silesia in Katowice, Poland

\section{References}

1. De Boeck K, Wilschanski M, Castellani C, et al. Diagnostic Working Group. Cystic fibrosis: terminology and diagnostic algorithms. Thorax. 2006; 61(7): 627-635, doi: 10.1136/thx.2005.043539, indexed in Pubmed: 16384879 .

2. Sagel SD, Wagner BD, Anthony MM, et al. Sputum biomarkers of inflammation and lung function decline in children with cystic fibrosis. Am J Respir Crit Care Med. 2012; 186(9): 857-865, doi: 10.1164/rccm.2012030507OC, indexed in Pubmed: 22904182.

3. Cohen-Cymberknoh M, Kerem E, Ferkol T, et al. Airway inflammation in cystic fibrosis: molecular mechanisms and clinical implications. Thorax. 2013; 68(12): 1157-1162, doi: 10.1136/thoraxjnl-2013-203204, indexed in Pubmed: 23704228.

4. Dhaliwal J, Leach S, Katz T, et al. Intestinal inflammation and impact on growth in children with cystic fibrosis. J Pediatr Gastroenterol Nutr. 2015; 60(4): 521-526, doi: 10.1097/MPG.0000000000000683, indexed in Pubmed: 25539196.

5. Moriconi N, Kraenzlin M, Müller B, et al. Body composition and adiponectin serum concentrations in adult patients with cystic fibrosis. J Clin Endocrinol Metab. 2006; 91(4): 1586-1590, doi: 10.1210/jc.2005-2135, indexed in Pubmed: 16464949.

6. Wang C. Obesity, inflammation, and lung injury (OILI): the good. Mediators Inflamm. 2014; 2014: 978463, doi: 10.1155/2014/978463, indexed in Pubmed: 24899788.

7. Ouchi N, Parker JL, Lugus JJ, et al. Adipokines in inflammation and metabolic disease. Nat Rev Immunol. 2011; 11(2): 85-97, doi: 10.1038/ nri2921, indexed in Pubmed: 21252989.

8. Misra M, Klibanski A. Endocrine consequences of anorexia nervosa. The Lancet Diabetes \& Endocrinology. 2014; 2(7): 581-592, doi: 10.1016/ s2213-8587(13)70180-3.

9. Olveira G, Olveira C, Gaspar I, et al. Fat-free mass depletion and inflammation in patients with bronchiectasis. J Acad Nutr Diet. 2012; 112(12): 1999-2006, doi: 10.1016/j.jand.2012.08.013, indexed in Pubmed: 23174686.

10. Steppan CM, Bailey ST, Bhat S, et al. The hormone resistin links obesity to diabetes. Nature. 2001; 409(6818): 307-312, doi: 10.1038/35053000, indexed in Pubmed: 11201732.

11. Holcomb IN, Kabakoff RC, Chan B, et al. FIZZ1, a novel cysteine-rich secreted protein associated with pulmonary inflammation, defines a new gene family. EMBO J. 2000; 19(15): 4046-4055, doi: 10.1093/emboj/19.15.4046, indexed in Pubmed: 10921885. 
12. Fantuzzi G. Adiponectin and inflammation: consensus and controversy. J Allergy Clin Immunol. 2008; 121(2): 326-330, doi: 10.1016/j. jaci.2007.10.018, indexed in Pubmed: 18061654.

13. Tatemoto $K$, Hosoya $M$, Habata $Y$, et al. Isolation and characterization of a novel endogenous peptide ligand for the human APJ receptor. Biochem Biophys Res Commun. 1998; 251(2): 471-476, doi: 10.1006/bbrc.1998.9489, indexed in Pubmed: 9792798.

14. Kleinz MJ, Davenport AP. Emerging roles of apelin in biology and medicine. Pharmacol Ther. 2005; 107(2): 198-211, doi: 10.1016/j.pharmthera.2005.04.001, indexed in Pubmed: 15907343.

15. Bełtowski J. Apelin and visfatin: unique. Med Sci Monit. 2006; 12(6): RA112-RA119, indexed in Pubmed: 16733497.

16. Boucher J, Masri B, Daviaud D, et al. Apelin, a newly identified adipokine up-regulated by insulin and obesity. Endocrinology. 2005; 146(4): 1764-1771, doi: 10.1210/en.2004-1427, indexed in Pubmed: 15677759.

17. Kawamata Y,Habata Y, Fukusumi S, et al. Molecular properties of apelin: tissue distribution and receptor binding. Biochim Biophys Acta. 2001; 1538(2-3): 162-171, doi: 10.1016/s0167-4889(00)00143-9, indexed in Pubmed: 11336787.

18. Wang G, Anini Y, Wei W, et al. Apelin, a new enteric peptide: localization in the gastrointestinal tract, ontogeny, and stimulation of gastric cell proliferation and of cholecystokinin secretion. Endocrinology. 2004; 145(3): 1342-1348, doi: 10.1210/en.2003-1116, indexed in Pubmed: 14670994

19. Xie H, Tang Sy, Cui Rr, et al. Apelin and its receptor are expressed in human osteoblasts. Regul Pept. 2006; 134(2-3): 118-125, doi: 10.1016/j. regpep.2006.02.004, indexed in Pubmed: 16563531.

20. Kleinz MJ, Skepper JN, Davenport AP. Immunocytochemical localisation of the apelin receptor, APJ, to human cardiomyocytes, vascular smooth muscle and endothelial cells. Regul Pept. 2005; 126(3): 233-240, doi: 10.1016/j.regpep.2004.10.019, indexed in Pubmed: 15664671.

21. Ziai S, Belson L, Malet A, et al. The association between leptin and insulin levels in adults with cystic fibrosis. Diabetes Metab. 2012; 38(1): 34-39, doi: 10.1016/j.diabet.2011.07.003, indexed in Pubmed: 21925915.

22. Cohen RI, Tsang D, Koenig S, et al. Plasma ghrelin and leptin in adult cystic fibrosis patients. J Cyst Fibros. 2008; 7(5): 398-402, doi: 10.1016/j. jcf.2008.02.002, indexed in Pubmed: 18353734.

23. Smyth AR, Bell SC, Bojcin S, et al. European Cystic Fibrosis Society. European Cystic Fibrosis Society Standards of Care: Best Practice guidelines. J Cyst Fibros. 2014; 13 Suppl 1: S23-S42, doi: 10.1016/j.jcf.2014.03.010, indexed in Pubmed: 24856775.
24. Kawanami D, Maemura K, Takeda N, et al. Direct reciprocal effects of resistin and adiponectin on vascular endothelial cells: a new insight into adipocytokine-endothelial cell interactions. Biochemical and Biophysical Research Communications. 2004; 314(2): 415-419, doi: 10.1016/j. bbrc.2003.12.104.

25. Ballantyne D, Scott H, MacDonald-Wicks L, et al. Resistin is a predictor of asthma risk and resistin:adiponectin ratio is a negative predictor of lung function in asthma. Clin Exp Allergy. 2016; 46(8): 1056-1065, doi: 10.1111/cea.12742, indexed in Pubmed: 27079485.

26. Kumor-Kisielewska A, Kierszniewska-Stepień D, Pietras T, et al. Assessment of leptin and resistin levels in patients with chronic obstructive pulmonary disease. Polish Archives of Internal Medicine. 2013; 123(5): 215-220, doi: 10.20452/pamw.1724

27. Bianco A, Nigro E, Monaco ML, et al. The burden of obesity in asthma and COPD: Role of adiponectin. Pulm Pharmacol Ther. 2017; 43: 20-25, doi: 10.1016/j.pupt.2017.01.004, indexed in Pubmed: 28115224.

28. Panagopoulou P, Fotoulaki M, Manolitsas A, et al. Adiponectin and body composition in cystic fibrosis. J Cyst Fibros. 2008; 7(3): 244-251, doi: 10.1016/j.jcf.2007.10.003, indexed in Pubmed: 18068553.

29. Ziai S, Elisha B, Hammana I, et al. Normal total and high molecular weight adiponectin levels in adults with cystic fibrosis. J Cyst Fibros. 2011; 10(6): 483-486, doi: 10.1016/j.jcf.2011.07.005, indexed in Pubmed: 21852205.

30. Hammana I, Malet A, Costa M, et al. Normal adiponectin levels despite abnormal glucose tolerance (or diabetes) and inflammation in adult patients with cystic fibrosis. Diabetes Metab. 2007; 33(3): 213-219, doi: 10.1016/j.diabet.2007.01.004, indexed in Pubmed: 17418606.

31. Lavie M, Fisher D, Vilozni D, et al. Glucose intolerance in cystic fibrosis as a determinant of pulmonary function and clinical status. Diabetes Res Clin Pract. 2015; 110(3): 276-284, doi: 10.1016/j.diabres.2015.10.007, indexed in Pubmed: 26508676.

32. Berry M, Brightling C, Pavord I, et al. TNF-alpha in asthma. Curr Opin Pharmacol. 2007; 7(3): 279-282, doi: 10.1016/j.coph.2007.03.001, indexed in Pubmed: 17475560.

33. Szadkowska A. Adipokiny [W:] Urban M. red Miażdżyca u dzieci i młodzieży. Cornetis wyd 1 2007: 268-285.

34. Mądry E, Nowak J, Wykrętowicz A, et al. Predicting the risk of atherosclerosis in patients with cystic fibrosis - rationale and design of a prospective cohort study. JMed Sci. 2015; 2: 126-128. 